OPEN ACCESS

Johnston, R., Harris, R. J., Jones, K., Manley, D. J., Sabel, C. E., \& Wang, W. W. (2014). One step forward and two steps back to the proper appreciation of spatial science. Dialogues in Human Geography, 4(1), 59-69. https://doi.org/10.1177/2043820614526818

Peer reviewed version

Link to published version (if available):

$10.1177 / 2043820614526818$

Link to publication record in Explore Bristol Research

PDF-document

This is an extened version of our reply

University of Bristol - Explore Bristol Research

General rights

This document is made available in accordance with publisher policies. Please cite only the published version using the reference above. Full terms of use are available:

http://www.bristol.ac.uk/red/research-policy/pure/user-guides/ebr-terms/ 


\section{One Step Forward but Two Steps Back to the Proper Appreciation of Spatial Science}

This paper is an extended reply to critics and comments on our original paper that had to be shortened due to journal space requirements.

The original paper is

Ron Johnston, Richard Harris, Kelvyn Jones, David Manley, Clive E Sabel, and Wenfei Winnie Wang (2014) Mutual misunderstanding and avoidance, misrepresentations and disciplinary politics: spatial science and quantitative analysis in (United Kingdom) geographical curricula Dialogues in Human Geography 2014; 4:3-25 doi:10.1177/2043820614525706 see: http://dhg.sagepub.com/content/4/1/3.abstract.html?etoc

The reply as published in its shortened form is:

Ron Johnston, Richard Harris, Kelvyn Jones, David Manley, Clive E Sabel, and Wenfei Winnie Wang (2014) One step forward but two steps back to the proper appreciation of spatial science Dialogues in Human Geography 2014; 4:59-69 doi:10.1177/2043820614526818

See http://dhg.sagepub.com/content/4/1/59.abstract.html?etoc

The full debate is to be found at

Dialogues in Human Geography, March 2014; Vol. 4, No. 1

http://dhg.sagepub.com/content/4/1?etoc 


\title{
One Step Forward but Two Steps Back to the Proper Appreciation of Spatial Science
}

\begin{abstract}
Several of the commentaries on the original paper made valuable contributions to one of its goals - promoting discussion about the contents of quantitative methods curricula for human geography undergraduate and postgraduate courses. But the only commentary relevant to the other goal, promoting a fuller understanding of contemporary spatial science across the entire discipline, was disappointing, raising new critical issues - regarding, for example, the use of place and of data collected from individuals in spatial scientific studies. These are responded to in this reply to the commentaries.
\end{abstract}

\section{Keywords}

Spatial science, quantitative human geography, place, data, curricula

The goal of our initial contribution to this dialogue (Johnston et al., 2014) was to consolidate the place of 'spatial science' within contemporary human geography (with particular reference to the UK), not by pressing its claims against other approaches we believe should be marginalised or eliminated (we don't think there are any), but rather by ensuring that all practitioners and students engage with its contributions, actual and potential, to the discipline's raison d'être. The paper addressed two main issues: the first was to overcome the mis-understandings and (quite possibly unintended) mis-representations of 'spatial science' that are too common in the contemporary literature, especially introductory textbooks; the second was to initiate debates about what those parts of a curriculum advancing quantitative understanding might contain, given major changes in the volume and nature of data now available.

Our reaction to the solicited commentaries is that we have been much more successful in the latter than the former task: several make important contributions to the discussion on what should be taught within the undergraduate and postgraduate curricula, how, and why. However, we were disappointed that none indicated we had made any headway in convincing those who are not 'spatial scientists' that contemporary work in this area should be recognised as an integral part of geography's task of understanding the contemporary world not simply as a transferable skill associated with numeracy and employment (although that is important too) but as a rich area of contemporary research that sits at the very heart of the discipline and its substantive interests. Hence much of this response seeks to advance that purpose yet again.

\section{Two Steps Back! What is spatial science, what does it do, and why is it important?}

Spatial science is our (and others') shorthand description for a wide range of work characterised by the use of numerical data and statistical analysis that might also be described as quantitative human geography. We are aware that other authors might use the same term to describe a particular epoch in geography's history, referring to the period of the so-called 'theoretical and quantitative revolutions' of the 1950s-1960s. Although we could debate the detail of that period, our main concern is that it is often presented as history - something that has been and gone, or perhaps lingers at the margins of the discipline (the ghost of positivism past?). The main concern of our paper was to argue that this notion of past tense is 
inappropriate, as is the idea that what remains of spatial science today has not evolved either in practice or in its philosophical underpinnings from what took place some decades ago. Nobody, we hope, would suggest that cultural geography has not changed since Carl Sauer, yet spatial science seems to us too frequently mis-interpreted, notably by those writing textbooks for introductory undergraduate courses who present it as not having evolved. ${ }^{1}$

David O'Sullivan wonders if we haven't over-reacted to a few such texts, being oversensitive and seeing disrespect where none is intended. We can assure him that some 'spatial scientists' at least have experienced such disrespect, including colleagues briefing against some of us to our own students (examples were quoted in our footnotes). We are also well aware of widespread lack of appreciation of what we do (in part reflecting under- and postgraduate course offerings in many places over the last two decades), of unwillingness to address those lacunae, and of a desire among some at least of our peers to place spatial science on the disciplinary margins, if not relegated to its past. ${ }^{2}$ Trevor Barnes believes that we over-state the difference between spatial science then (i.e. pre-1980) and now, but generalises from a sample of one; we contend that Abler, Adams and Gould, Golledge, Haggett, Harvey (pre-1973), King, Wilson and others were much more influential in setting spatial science's trajectory than Bill Warntz and the macro-geographers/social physicists. ${ }^{3}$

We admit, however, that what we identify as a lack of appreciation may also be a product of a lack of understanding. It has been suggested, for example, that quantitative geographers have been slow to engage in some of the philosophical debates concerning constructions of knowledge within human geography. Although not entirely valid (witness some of the debates around GIS and its purposes in the 1990s: for example, Pickles, 1995, and Curry, 1998), there is, perhaps, truth in an argument that spatial scientists have been slow to showcase the importance of what they do to the discipline, and to new generations of scholars and students. There is a responsibility on our part to be more involved in the (co-)production of such texts in the future.

\section{Spatial science: what it was and what it is}

The main response to the first part of our paper, however, is Cresswell's; when writing our original paper his book was the most recent exemplar of the problems we identified as too common in contemporary texts. It is important to restate at this point that on the whole we found much to admire in his book. Moreover, and lest it be seen that we are overly preoccupied by the writings of one author, we should emphasise that his mis-representations of spatial science as largely mired in the 1960s are not unique. Indeed, a more recent text the third edition of a best-seller - makes exactly the same claims regarding spatial science's marginality (Cloke, Crang and Goodwin, 2014, xxii-xxiii and 940), presenting it as not having changed from:

\footnotetext{
${ }^{1}$ The focus is on introductory textbooks since these are the only public arena in which geographers of one persuasion feel it necessary to address the work of those of another. In their own research, especially given the plethora of specialist journals, they can readily ignore it.

${ }^{2}$ One of us (Johnston 1984, 1985, 1997) has long argued that the form that spatial science took in its early decades was too constrained - O'Sullivan noted only one of those items!

${ }^{3}$ Incidentally, one of the pioneers of that type of work - George Zipf - did promote a 'principle of least effort', surely a positivistic approach, and the concept of population potential is under-pinned by the gravity model, which assumes the sort of rational behaviour Barnes claims Warntz did not assume: and although Stewart and Warntz may not have resolved the computational issues until 1958, Chauncy Harris (1954) had done so in a tooforgotten earlier pioneering paper.
} 
... an approach to Human Geography that became influential in the 1960s by arguing that geographers should be concerned with formulating and testing theories of spatial organisation, interaction and distribution. The theories were often expressed in the forms of models - of, for instance, land use, settlement hierarchy, industrial location and city sizes. If validated, these theories were then accorded the status of individual laws. Through this manoeuvre, the advocates of spatial science claimed that Human Geography had been shifted from an essentially descriptive enterprise concerned with the study of regional differences to a predictive and explanatory science. Critics claim that in its attempts to formulate universally applicable laws, spatial science ignored the social and economic context within which its spatial variables were located.

Cloke et al.'s book has three goals (p.xv): to map out 'the big, foundational ideas that have shaped the discipline past and present'; to explore 'key research themes [now] being pursued in Human Geography's various sub-disciplines'; and to identify 'some of the current research foci that are shaping the horizons of the subject'. Spatial science certainly plays no part in the second and third of those - in the editors' view it is not contributing to the discipline's key research themes and so students need not be introduced to its work - and appears only as part of the past in the first (and then it is unclear whether they classify it as a 'big, foundational idea' - in contrast to Cox, 2014, who sees it as fundamental). ${ }^{4}$ A book written for 'students new to university degree courses' basically ignores contemporary spatial science and further justifies our goal as set out in the introduction above. Its editors claim that human geographers "argue both that human life is shaped by "where it happens" and that "where it happens" is socially shaped' (p.xvii) - which is exactly what much contemporary spatial science demonstrates. Alongside Cresswell, however, they see quantitative work as descriptive only (p.xxii: Little - 2014, 26 - also implies that quantitative analysis can describe but not explain and equates spatial science with 'a kind of spatial determinism in which spatial difference caused social inequality' - p. 25, her emphasis - and a 'belief that space was passive')! Explanation and causation are very much on the contemporary agenda across quantitative social science and there is considerable interest and progress in how we can do this with observational and not experimental data - witness the 1600+ pages of Davis (2014) and also Gangl (2010). ${ }^{5}$

Cloke et al. (2014) is not entirely lacking reference to more recent work in spatial science as in: Kitchin's careful discussion of the difference between explanation and understanding, which clearly identifies the methodological and philosophical distinctions between quantitative and qualitative work but without (understandably) any detailed illustrations of the types of analysis conducted in contemporary spatial science; and Conradson's (2014) brief mention, but without exemplars, of the epidemiological tradition in the geography of health and well-being. There is also a chapter on GIS (though not GI Science): it asserts that GIS facilitates data collection, analysis and modelling, but provides no examples of the latter two (Haklay, 2014); instead, it seems more concerned to advance engagement between GIS

\footnotetext{
${ }^{4}$ Gilbert (2014, 103-104) compares the Cloke et al. (2014) book with Haggett's (1972ff) Geography: a Modern Synthesis and remarks that 'there is little direct application in this volume [i.e. the former] of the approaches that Haggett heralded', with the clear implication to student-readers that those approaches - 'formulating and testing theories of spatial organization' (Christaller and von Thünen once again!) - are no longer part of human geography. Quoting the work of Dorling, Gilbert accepts the 'power of numbers and maps as an important element of a critical social science' but dismisses the modelling work done at the Centre for Advanced Spatial Analysis (CASA: http://www.bartlett.ucl.ac.uk/casa) and elsewhere, which he identifies as positivism (though we doubt that the researchers there do: see Batty, 2013)

${ }^{5}$ Or http://csm.lshtm.ac.uk/themes/causal-inference/ (accessed 27 January 2014).
} 
and 'critical human geography' than with spatial science. ${ }^{6}$ Nowhere in a book of over 900 pages, however, is the full range of spatial science's powerful contemporary arsenal engaged with when introducing the diversity of contemporary human geography and there are no illustrations of what can be achieved through rigorous quantitative analysis of data. There is an acceptance that students should have some introductory training in numerical methods but no willingness to address why. The risk is that books like Cresswell's and Cloke et al.'s plus others and, perhaps, many lectures, seminars and tutorials - end-up normalising the discipline (Luke, 1999: see also Klein, 1993; Amariglio et al. 1993; and Lenoir, 1993) according to their conceptions of what it should and should not contain rather than presenting introductory students with a broad conspectus of its diversity of practices and letting them decide.

Another recent book poses the same set of issues. In a generally very fine 'pocket dictionary', Castree, Kitchin and Rogers $(2013,486)$ give two definitions of spatial science. The first 'An approach to human geography centred on the analysis of spatial patterns and processes through quantitative methods, with the ultimate aim of establishing spatial laws' - is very similar to those of Cresswell and Cloke et al., especially with regard to laws, and the subsequent discussion clearly identifies such work as concentrated in the 1950s-1970s. The second definition - 'A collective term for GIS, cartography, remote sensing, photogrammetry, surveying, geodesy, and related disciplines concerned with scientific spatial analysis, sometimes also termed "spatial sciences" - which they suggest is "often used to imply a set of academic and technical interests separate from but also complementary to geography'. Their definition of locational analysis is synonymous with that for spatial science (p.291) and spatial analysis is defined as (pp.480-1) 'The mapping and analysis of spatial properties and patterns', which would appear to incorporate much of what we have included as part of contemporary spatial science here and in our original paper, but the brief definition concludes that 'With the development of GIS, spatial analysis has become a mainstream policy tool for making sense of spatial data and for aiding companies to plan their activities' - which is much narrower than our definition of spatial science. They do, however, note that 'While quantitative geography is not as dominant as it once was, it is still a potent and vital part of the discipline' (p.406) - exactly our point: so does Cox (2014, pp.53, 154-158, and 255), whose personal interpretation of changes in human geography over the preceding 50 years very much regrets the 'marginalization of quantitative methods in human geography' (p.255). ${ }^{7}$

What we in this and our preceding paper - and following Cresswell's (2013) own usage of the term, to which we were responding-call spatial science may therefore be associated by some with pre-1980s practices, whereas more contemporary work, because it distances itself from logical positivism, is simply embraced by the collective title of quantitative geography. However, Cresswell's comments in his contribution to this dialogue suggest that he does not make this distinction - nor, we believe, do Cloke et al., 2014, and others - and spatial science to them not only incorporates the contemporary work but associates it with the logical positivist search for laws of spatial patterns and behaviour rather than - as we stressed in the

\footnotetext{
${ }^{6}$ Haklay's (2014) illustrations of the utility of GIS refer only to business applications with no reference to their analytic utility.

${ }^{7}$ Cox $(2014,156$ : our emphasis) is also explicit, unlike the textbook writers cited here, that 'Quantitative geography was positivist' but 'could do [we would say has done] more than identify "descriptive 'representative generalizations, lacking in explanatory penetration”. Rather, some spatial-quantitative work has been [and still is] concerned with uncovering mechanisms of the sort that Sayer believes are only accessible through "intensive methods"' (p.138: his emphasis: the reference to Sayer is Sayer, 1992).
} 
paper which initiated this dialogue - the identification and analysis of spatial variations and the search for explanatory accounts in the realist not the positivist tradition. ${ }^{8}$ Hence this response to Cresswell's commentary, in which he extends his critique of such work. ${ }^{9}$

Cresswell believes that he was relatively kind to and positive about spatial science in his book (Cresswell, 2013) - that is probably true yet the problem (as we have emphasised) is one of writing the past whilst not fully appreciating the present. He may have found some spatial science work 'Inspirational and compelling', may believe that it has 'the capacity to influence the world for the better in ways that few other approaches can', and may very well be right that one of the reasons for spatial science's unpopularity is that too few teachers of quantitative methods are able to 'turn students on' (hence our other goal here) - or even some of their own departmental colleagues. But it is very difficult to equate his statements regarding spatial science's 'capacity to influence the world for the better' with the representations in his book (which we cited in our original paper - p. ???): how can analyses which assume 'a particular kind of imaginary person' and start with something 'that is not true' contribute to improving the world or convince students that this is an area of scholarship worth exploring?

\section{Place in spatial science}

...place - especially as manifested in neighbourhoods - is a fundamental context that has widespread effects on crime, perceptions of order and disorder, well-being and much more, including the social organization of the contemporary metropolis (Sampson, 2013, 1)

Numerous writers suggest that geography's key concepts are 'space, place and environment' (Johnston and Sidaway, 2014) and it was in this context that we indicated that spatial scientists today pay much more attention to place than to space. Place, as we and Cresswell (2014) appreciate, has many meanings and quasi-synonyms, but his comment that 'Place is not the same as "local variation" and that our usage appears 'at best, a shallow conception of place that really has to be experienced experientially and from inside' seems not only to privilege a particular definition but also to avoid addressing our core argument that, to quote Cloke at al. again, "human life is shaped by "where it happens" and ... "where it happens" is socially shaped' - i.e. in places (or locales, or localities, or territories, or milieux, or...). Cresswell claims that he cannot tell from our examples 'how place is present in spatial science - or even that it should be': extremely rigorous quantitative work has shown, for example, that the peer groups young people are brought up among (i.e. those who share their places at a particular scale) can influence their academic performance (Goux and Maurin, 2007). ${ }^{10}$

\footnotetext{
${ }^{8}$ This does not mean that we do not believe that the subject matter of the spatial sciences does not include regular patterns - which in some cases might be regular spatial patterns - but we do not argue that these regularities explain themselves. Nor do we believe- as was claimed in many of the early criticisms of positivist spatial science - that public policy should reproduce the status quo transient regularities, nor equate explanation with prediction. We are scientific and rigorous in our analyses but do not accept the tenets of logical positivism; see Jones (2010) and Johnston (1986).

${ }^{9}$ We are not alone in seeking to move forward from the type of spatial science practices critiqued by Cresswell: see, for example, Baudains et al., (2013), Cook et al., (2011), Elwood (2006) and Kwan (2002) - some of which are breaking down the barriers between spatial science and other human geographical practices.

${ }^{10}$ Alternatively, see Syed's $(2011,3-7)$ discussion of the influence of spatial clustering on the development of a group of highly successful sportspersons, and his conclusion that if his parents had bought the house next door to the one that they did, then he would never have become a champion table-tennis player.
} 
More generally, Cresswell's view that the 'contemporary focus in spatial science on local variability sounds like a numerical version of regional geography' further illustrates his misinterpretation of what he terms a wider 'culture of numbers'. Regional geography as practised in the UK up to the 1970s suffers from a poor reputation but was not all bad, although much of it - as Peter Gould (1979) so gloriously showed - was banal and boring. ${ }^{11}$ Nevertheless at its best - which includes many of the introductory courses and texts for US undergraduates who have no prior experience of the discipline - it ensured that students knew the basic lineaments of the wider world and gave them some appreciation of 'place' as Cresswell defines it (can one understand the world unless one can first describe it?). He believes that spatial scientists' deployment of place - as we present it - is simply a description of 'what things gather where'. It is much more than that, however, because its analyses show that which people gather, and in many cases interact, where can influence what things happen there and may be transmitted elsewhere (near or far), of which there is no better illustration than the decades of meticulous quantitative research in the epidemiological tradition by Cliff, Haggett and Smallman-Raynor (e.g. Cliff et al., 2000). Place to spatial scientists is a context in which things happen, because the place is constituted by people who interact there, and a recent overview of American research in this area (such as the extensive programme led by Sampson, 2012) has concluded not only that 'the American system of stratification is organized, in part, along spatial lines' but also that the spatial dimension of American inequality plays an important role in the maintenance and reproduction of inequality across multiple dimensions' (Sharkey and Faber, 2014). In a world where inequalities are increasing (Wilkinson and Pickett, 2009; Dorling, 2010) it seems perverse not to focus on the role of places as contexts in which those inequalities are being reproduced and exacerbated as the examples quoted here and in the concluding section clearly illustrate.

\section{Counting the individual}

One major change in the nature of spatial science in particular and social science more generally in recent decades has been its increasing use - and collection - of data at the individual rather than the aggregate scale, thus avoiding the ecological and other fallacies that so many earlier studies encountered, as well as the modifiable areal unit problem. ${ }^{12}$ Cresswell is 'far from sure that I want to celebrate the entry of the individual into the domain of calculability', because of issues of privacy and surveillance as well as 'a more existential set of issues about the reduction of human subjectivity'. He asks 'Do we want individuals to be quantified in this way? Do we want to encourage it by using the data?'. Our answer is a resounding yes - we do want students to be savvy users of useful data that, yes, may well be the product of capitalist or 'surveillance' societies but can also be used to inform, critique, and to reveal the shortcomings and social disparities within those societies. Does that mean we are unwitting co-producers of a society driven by cold quantitative and economic logics? Perhaps so. But so also are those who are unwilling to turn the numbers against themselves and use them to engage in social and other public policy relevant critique. We fully recognise the problems of privacy and confidentiality, and believe that students should be trained to do so too - issues that Elvin Wyly addresses fully in his commentary - and ensure that our collection and analysis of data compromise neither, but we firmly believe that without such data many important issues could not be fully addressed and compelling problems would remain unresolved. This is clearly illustrated in much spatial science research which

\footnotetext{
${ }^{11}$ To the extent that some of its practitioners subjected it to substantial criticism - see Freeman $(1961,141)$.

${ }^{12}$ Which government might have been formed after the 2010 and 2015 general elections is a superb illustration of the relevance of this problem (Johnston et al., 2013).
} 
indicates, for example, that without individual data it is impossible to elucidate the relative importance of genetic and environmental factors (let alone their interactions) on disease causation (Sabel et al., 2009) and appreciate the mortality impacts of environmental events (Pearson et al., 2013). ${ }^{13}$ To illustrate the problems that can arise when groups are used to make inferences because individual data are not available consider the case of gender bias in admissions to the University of California, Berkeley (Bickel et al, 1975). Overall, men applying were considerably more likely than women to be admitted but when individual data were examined by department there was no evidence of bias - because males tended to apply to less-competitive departments. Students need to be fully aware of this paradox and its geographical equivalent, the ecology fallacy, in making inferences with aggregate data.

We have never claimed that the approaches we promote 'even begin to approach our subjectivity', nor would we argue that research in cultural geography focusing on subjectivity (whose 'data' must presumably be collected from individuals?) should not occupy a prominent place within our discipline. We simply contend that there is more to studying and trying to change the world than subjectivity.

We live in a capitalist society in which the state is necessarily important (the Free Economy and Strong State so brilliantly described by Andrew Gamble, 1988), and in which more and more Big Data are being 'pumped out by corporations, governments and the media'. We agree with Cresswell that students should 'know enough to question the stream of numbers' but disagree with his wish that they should not be 'part of the making of a comprehensively calculable world'. They are going to be, whether he, we and they like it or not and we see it as necessary that they are prepared to be citizens of such a world (however undesirable we might think that is idealistically). Yes, those data are involved in the "production of profit and the manipulation of populations' so our teaching should ensure that students are aware of that, which means much more than ensuring that they 'know what correlation means (even just to know that it is still not causation)'. Our argument is represented by him as 'Big businesses, governments and an assortment of ill-intentioned people know about numbers and use them therefore we (well-intentioned) people must do so too'. Yes, but that does not make us the lackeys of corporate capitalism and governments; we are social scientists ensuring that students become citizens who can evaluate how those (often well-intentioned) people collect and use data as well as ensuring that, as far as possible, they are used for the greatest good of the greatest number. ${ }^{14}$ As Thompson $(2010,381)$ expressed it when making the case for retaining a decennial census in Canada, high quality data are needed not only to inform decision-making but also 'to allow the society to question and judge whether or not the government is acting in its best interests'.

Nevertheless, we clearly share Cresswell's concerns - more extensively expounded by Wyly - about the intrusiveness of much Big Data production, notably by corporations. There is however a difference between data obtained through covert surveillance and that given either freely - because you use a credit card or a store loyalty card, or leave your mobile phone on permanently - or as part of one's civic duty, as with data collected by a democraticallyaccountable government in order to pursue its policies (as with censuses: see Hannah, 2010,

\footnotetext{
${ }^{13}$ Incidentally, one of the quantitative papers that Cresswell $(2013,100)$ cites favourably was entirely based on individual-level data.

${ }^{14}$ Cresswell says that throughout our paper there are references to 'the use of quantitative methods in government and business'. We don't apologise for that, we live in the world where that is the case - though interestingly unless various search engines have let us down the word 'business' did not appear even once in our original paper!
} 
about citizen opposition to such data collections and particular forms of their use). The UK government, through its open data initiatives, is increasingly making such data available for public use in situations where there is no conflict with individual and group confidentiality and privacy, thereby enabling both critical analysis and well-founded contributions to policy development. ${ }^{15}$ Exeter et al. (2014) have recognised the potential problems with such use and release of individual-level, geocoded data with regard to confidentiality and the absence of consent; a balance has to be reached between the benefits to be gained and the possible misuses that might be facilitated if geoprivacy is not ensured. They argue strongly that without the properly-regulated release of expensively-collected individual-level data, advances in the understanding of, and responses to, morbidity and mortality patterns will be significantly impeded.

We too do not favour a society in which, as Wyly expresses it, 'Human trust is under siege, replaced by an expanding universe of surveillance'. But we believe - in common with all but the most extreme market-libertarians - that a civilised society needs some form of welfare state to tackle the five 'Giant Evils' identified by Beveridge - Want, Disease, Ignorance, Squalor, and Idleness (Timmins, 1995). Although policies designed to tackle each of those five are ultimately aimed at individuals many are delivered to them within collectivities - as with schools and hospitals - and the data on which many policies to determine what should be delivered, to whom, and where are necessarily for population aggregates, not individuals. Analyses conducted by academic social scientists and those in the public sector trained in their methods - using place as context, whether in studies of unemployment, morbidity and mortality, poverty or a wide range other topics - are fundamental to appreciation of where the problems that the welfare state exists to solve are concentrated and thus the where of its policy directions (Bastow et al. 2014; Denicolo, 2013).

There is, however, one element of the 'domain of calculability' not addressed by Cresswell that requires caution. Counting and, especially, the reporting of what we have counted frequently involves categorisation of individuals, and in so doing structures society in ways that then become part of how it is represented and reproduced. The earliest censuses did this, for example, by not only counting how many individuals there were in a place but also what categories - such as occupational classes - they were members of (Levitan, 2011). Some of those categories are straightforward and (relatively) uncontestable, such as age and sex, but many others are highly contested, such as the much-debated ethnicity categories deployed by the UK's Office of National Statistics (Berthoud, 1998; Aspinall, 2007). This involves what has been termed the 'mutual construction of statistics and society' (Sætnan et al, 2011), with much of that construction undertaken (especially by social scientists) by and for the state to promote its governance objectives - and, some would argue, the exercise of power by those controlling the state bureaucracies (see the essays by Desrosières, 2011, and Kullenberg, 2011). ${ }^{16}$ Those categorisations can be arranged along an objective-subjective scale: as they approach the latter, so they need to be treated with more caution because of the difficulty of measuring many concepts - as with the 'happiness index' invented for the UK Prime Minister in $2011 .{ }^{17}$ Any curriculum focusing on quantitative spatial science must ensure student awareness of the social construction of many of the categories that are analysed and the role

\footnotetext{
${ }^{15}$ See http://data.gov.uk/ - accessed 7 January 2014.

16 The corporate sector is also involved in such structuring: the socio-economic categorisations developed with geodemographic classifications of people-in-places, for example, are now major marketing tools (Longley and Clarke, 1995; Harris et al, 2005).

${ }^{17}$ See http://www.ons.gov.uk/ons/guide-method/user-guidance/well-being/index.html (accessed 15 January 2014).
} 
of such analysis in how socio-spatial structures are represented. But they must also become aware that measurement and categorization is not a simple and straightforward interpretive act and subjectivity brings its own problems. Thus Oakley $(1990,177)$, in her polemic 'Who's afraid of the randomized control trial', argues that 'random numbers have the edge over human intuition because human beings are not always right in the judgements they make'. Indeed she claims that quantitative experimental methods are a key part of emancipatory social science lest the ideology of researchers and practitioners is imposed on those being researched and the status quo is thereby maintained.

\section{One (Good) Step Forward: curriculum design for spatial science}

We are very grateful for the two commentaries that directly address the second component of our original paper - what should be included in a spatial science curriculum spanning (UK) under- and postgraduate degree courses - and also to Elvin Wyly's wider appreciation of the nature of 'Big Data'.

David O'Sullivan introduces two important correctives to our original paper. We accept that we underplayed the role of geometry within the evolving sub-discipline. This was something we debated when drafting the paper: our main concern was to stress that the emphasis on the geometry of spatial order that characterised early spatial science was no longer a major consideration, but in doing so we ignored much important work - such as that of Batty (2013) and his colleagues at University College London's Centre for Applied Spatial Analysis - that explores the spatial structuring of contemporary cities without reference to the homo economicus distance- and cost-minimisation assumptions of earlier modelling, ${ }^{18}$ as well as overlooking the geometric underpinnings of much cartographic analysis. Similarly, we had no intention of side-lining GIS/GISc, widely used in much quantitative analysis of spatial distributions: our position on these is that - as with remote sensing several decades ago what was for a time at the cutting-edge of spatial scientific work has now become mainstream. GIS is at the core of any viable spatial science curriculum, including the growing importance of visualisation as a key tool, whilst research at the frontier of software and hardware development (i.e. GISc) is concentrated in a few centres. O'Sullivan's comments have enabled us to emphasise these positions, which may have been lost in our initial arguments.

Chris Brunsdon's contribution takes our arguments forward in a number of important ways, and we were particularly attracted to his thoughts regarding 'Data journalism'. Some journalists are already well-trained in the quantitative arts. As Rogers $(2013,60)$ reports:

The Wikileaks releases on Afghanistan, Iraq and the US embassy cables; the MPs' expenses scandal; the global recession; even the swine flu pandemic: reporting on all of these was arguably only possible because of, and was irrevocably changed by, the existence of reporters who are not afraid of maths, know how to use a spreadsheet, work with the web visualisation tools and - crucially - know what questions to ask. The message needs to go beyond as well as through student communities - just as geographers did in earlier decades with regard to graphicacy via maps. Most of Brunsdon's points relate to the emergence of a 'Big Data paradigm' and its implications for social scientific (i.e. reproducible) research, however. Those data are not collected either by the

\footnotetext{
${ }^{18}$ Although note that in a recent textbook Alan Wilson (2000) has a chapter on 'classical models' that includes von Thünen, Weber, Christaller, Lösch, Burgess, Hoyt, and Zipf, selected as 'classics' because he believes that 'they are discussed in most geography textbooks' and 'cover the main geographical problems for which theory is in principle required' (p.50)
} 
analysts themselves or by others who have used a 'scientific' research design (such as census and official statistics authorities); conventional measures of statistical significance have little relevance with such large-N 'pseudo-samples' ${ }^{19}$ All of these issues need to be taken into account when designing courses that will prepare students for the Big Data world. As illustrated by the changing nature of quantitative methods textbooks over the five decades since the first published by a geographer (Gregory, 1963), the nature of the data students are presented with and/or collect calls for approaches that were unthinkable then, when samples were very small and computers very slow (if you even used one!).

Wyly takes the discussion of Big Data even further (as does the collection of brief papers in this journal convened by Graham and Shelton - 2013 - which only appeared after submission and acceptance of our original paper), debating whether as geographical scholars writing for an audience of scholarly geographers we really control the content of the curriculum, and whether any control that we have retained is under threat. Although we accept many of the concerns regarding surveillance (Graham and Wood, 2003) and the ways in which people not least elected politicians - may/will deploy Big Data in an empiricist framework to provide evidence sustaining their positions, we are not as pessimistic as Wyly. He believes that we (we assume he means the UK) have an 'educational system in which the audit culture is quickly destroying the conditions of possibility for uncommodified free thought and independent scholarly knowledge production'. We remain unconvinced by that argument. The UK's audit culture has been expanding rapidly since the first Research Assessment Exercise in 1985 and yet during the ensuing 25 years the sort of geography that Wyly believes will be repressed - 'a truly human geography - geography as understood, lived, performed, and learned by humans' - has blossomed, as exemplified by the amount of space given to approaches other than spatial science in the textbooks by Cresswell, Cloke et al. and others discussed here. And there is little evidence that such blossoming - which we welcome, so long as it doesn't crowd out other viable approaches through mutual mis-representations and ignorance - has only occurred because of some culture of resistance by geographers. Quite the contrary. Fears of a 'thought police' and a technocratic takeover of geography within British academia are much overblown. That does not, of course, mean that we shouldn't be eternally vigilant and ensure that students are aware of the many potential pitfalls of the Big Data paradigm and the possibility of the emphasis shifting from 'evidencebased policy' to 'policy-driven evidence manufacturing'. Geography flourishes as a broadbased discipline, and we have no intention of challenging that - let alone seeing it under challenge from 'outside authorities'.

\section{Why does it matter; why must this dialogue be continued?}

This is a time when the Mayor of London - a humanities graduate - does not understand that in a normalised distribution with 100 as its mean and a standard deviation of 15, 16 per cent of the respective population will always score below 85, that 2 per cent will always be above $130,{ }^{20}$ that IQ tests have to be re-calibrated every generation due to rising intelligence as measured in that way (the Flynn effect: Flynn, 2012), and that careful analysis of longitudinal data is needed to refute the IQ-income generation link! It is also the time when the head of the UK's school standards body (OFSTED) stated that all school students should obtain above average grades in English and the country's Secretary of State for Education implied

\footnotetext{
${ }^{19}$ Those designs can be 'replicated' with some big data sets, however, as with the weighting that is undertaken by opinion pollsters.

${ }^{20} \mathrm{See}$ http://www.telegraph.co.uk/news/politics/london-mayor-election/mayor-of-london/10480321/BorisJohnsons-speech-at-the-Margaret-Thatcher-lecture-in-full.html (accessed 3 January 2014).
} 
that all schools should strive to be good - and that this meant that their students performed above the average! $!^{21}$ This is a time when the work of two Harvard economics professors is used to justify a global austerity package based on a relationship between debt and growth spuriously created by an Excel-spreadsheet error and inverting the casual flow (Bell et al., 2014). This is a time when the UK's Home Secretary (trained in geography at the University of Oxford), when shaping an immigration bill, declared that feelings matter more than fact, ${ }^{22}$ and whose department replied to an EU request for the evidence about costs for 'health tourists' that 'We consider that these questions place too much emphasis on quantitative evidence'. ${ }^{23}$ This is a time when PISA evidence on international variations in school students' performance derived from standardised tests in reading, maths and science is being mis-used to restructure schools and the curriculum. ${ }^{24}$ This is a time when another Cabinet Minister in charge of reconstructing significant components of that country's welfare state (who appears to have dissembled about his post-18 education ${ }^{25}$ ) rejects evidence-based policy because he believes that what he is doing is right and good. ${ }^{26}$

This is a time when a mother wrongly convicted in the UK of murdering her children - and subsequently, after eventually being released on appeal, died of alcohol poisoning - was imprisoned because a key expert witness did not understand that the multiplication theorem of probabilities requires the events under consideration to be independent, and the court did not appreciate that the need to avoid the prosecutor's fallacy requires weighing up the relative likelihood of the two competing explanations for the children's deaths - although double Sudden Infant Death Syndrome (SIDS) fatalities in the same family are very rare, double infant murder in the same context is rarer still. The original analysis put the likelihood of two deaths at 1:73 million; a Bayesian analysis puts the relative likelihood at the odds ratio for double SIDS against double homicide at between 4.5:1 and 9:1. But Bayesian reasoning is not allowed in an English court. ${ }^{27}$

As these examples illustrate, there has never been a greater need for informed use of quantitative evidence and the widest possible appreciation of evidence and uncertainty. Addressing this issue requires a variety of approaches - as illustrated in the 'quasi-popular' books by Goldacre (2008, 2012), Silver (2012) and Blastland and Spiegelhalter (2013) - in which all levels of the educational system should play a role by ensuring a sufficiently numerate population who can appreciate and, where necessary, critique quantitativelyphrased arguments. Our case is not just that geography degree programmes should play a part in that educational process through introductory courses in enumeration (Cloke et al., 2004). ${ }^{28}$ Spatial science should be at the core of all such programmes, because it is so important, and will undoubtedly become even more so as Big Data increasingly come to

\footnotetext{
${ }^{21}$ See http://www.theguardian.com/politics/reality-check-with-polly-curtis/2012/mar/15/ofsted-chief-mathswrong (accessed 3 January 2014)

${ }^{22}$ See http://www.theguardian.com/commentisfree/2013/oct/12/theresa-may-health-tourism-facts (accessed 3 January 2014)

${ }^{23}$ See http://niesr.ac.uk/blog/benefit-tourism-commission-gives-us-some-facts (accessed 3 January 2014)

${ }^{24} \mathrm{See}$ http://www.bbc.co.uk/news/education-25336254 (accessed 3 January 2014): on the validity of the PISA tests see http://www.theguardian.com/news/2013/dec/03/pisa-methodology-education-oecd-studentperformance (accessed 3 January 2014) and Murphy (2010).

${ }^{25}$ See http://en.wikipedia.org/wiki/Iain_Duncan_Smith (accessed 3 January 2014)

${ }^{26} \mathrm{See}$ http://www.newstatesman.com/politics/2013/07/duncan-smith-rejects-evidence-based-policy-i-believebe-true (accessed 3 January 2014)

${ }^{27}$ See the articles on this and other cases in Significance 2(1) March 2005.

${ }^{28}$ But no more. Cloke et al. $(2004,283)$ describe enumeration in human geography as 'best seen as a form of thin description, capable of identifying certain characteristics and patterns of data, but incapable of describing or explicating the meaningful nature of life'.
} 
dominate much public and private sector decision-making (particularly if those data are increasingly drawn from unrepresentative commercial sources with no reliable benchmarking provided by high quality census enumerations: see the essays in Walton-Roberts et al., 2014). Whilst it remains the case that geography is a relatively numerate discipline, in schools and, in fact, in Universities in the UK, a recent report to the Royal Geographical Society (with IBG) raised concerns about students simply not having the computational or more 'advanced' skills needed to undertake quantitative research (or to compete with those from other countries where the training is to a much higher level: Harris et al., 2013). The ESRC's Benchmarking Review of Human Geography identifies similar concerns (ESRC, 2013).

Geography matters. To quote Cloke et al. again "human life is shaped by "where it happens" and ... "where it happens" is socially shaped'. Contemporary spatial science addresses that, through rigorous analyses across a wide range of subject matter - economic, social, political, and even cultural. It is much more than quantitative description; it is rigorous quantitative analysis of patterns, relationships and differences that can only be appreciated through the study of aggregates (albeit often bespoke aggregates created from individual - many of them geocoded - data) and which are not only important to understanding and accounting for the structuring of society but also in many cases highly relevant to policy development attempting to create a better, more equal and sustainable society. This is exemplified by a massive, ever-expanding volume of literature. As this response was being drafted several papers attracted our attention. One was a meta-analysis which demonstrated strong and consistent relationships between an individual student's educational performance and the characteristics (such as family income) of her/his classroom peers (Johnson, 2013); another showed that the incidence of mental illnesses in an area was significantly linked to crime rates there (Dustmann and Fasani, 2014); Norman and Boyle (2014) extended earlier work (Dibben and Popham, 2013; Green, 2013) exploring links between migration, areas of varying degrees of socio-economic deprivation, and age-specific death rates ('people live in different types of places at different stages in the life course'); and Rind et al. (2013) linked health inequalities within England to the geography of recent industrial decline. These, and many others, illustrate the structuration processes adumbrated by Cloke et al.: people make places and places make people.

The issues discussed in those papers - educational performance, crime, illness - have important subjective elements and as such are worthy of study. But each individual experience can also be treated as an 'objective' fact, albeit with a degree of measurement error (a doctor misdiagnosing a cause of death, for example), combined with other similar observations and subject to aggregate statistical analysis. It is then possible to uncover whether certain events or characteristics are significantly clustered into particular places, and - if that is the case - begin asking why (a question that may be posed before the data collection begins, of course, if either previous studies or theoretical arguments suggest plausible reasons that should be tested using rigorous analytical procedures). ${ }^{29}$ Only then can ameliorative action - tackling the spread of an infectious disease, for example, or reducing differences in life expectancy - be considered. Evidence-based policy requires much more than thin description of 'what things gather where'; it requires knowledge of why they are gathered there and the impacts of such clustering. Similar arguments can be made for evidence-based analyses of policy implementation - the efficacy of flood forecasting as a tool

\footnotetext{
${ }^{29}$ On the day when this manuscript was submitted to the editors, The Times (of London) carried an article entitled 'Poor boys who will not live to retirement' showing that within England life expectancy for babies born in 2014 varied from 67.8 in one place to 97.7 in another. (http://www.my-rss.co.uk/feeditem.php?feed=0\&word $=\&$ search $=\&$ item $=286837-$ accessed 27 January 2014).
} 
for ensuring that property-owners have viable insurance, for example; where people rely on food banks; and the impact of various changes in taxation systems (such as the 'bedroom tax'/'spare room subsidy' introduced in the UK in 2013: see Hamnett, 2013 ${ }^{30}$ ). Such evidence-based pre-policy and post-implementation analyses would hopefully ensure fewer government blunders of the frequency and magnitude described and analysed by King and Crewe (2013: see also Hall, 1980).

Unfortunately, those arguments are not accepted by all geographers. The commentaries by Brunsdon and O'Sullivan are from scholars already convinced by the case, which they have made stronger, whereas Wyly also appreciates the argument and points out some of the problems that those promoting the teaching of spatial science will (already do?) face given the 'Big Data revolution'. But, sadly, there is only one contribution from among the substantial number of unconvinced geographers and who, we fear, illustrates the 'mutual misunderstanding, avoidance and mis-representation, ${ }^{31}$ that is all-too-common in contemporary human geography. Cresswell indicates that his attitude towards spatial science reflects the failure of teachers to enthuse him about it when he was an under- and post-graduate. Our original paper clearly similarly failed to stimulate him - and perhaps others too - to address that mis-understanding and avoidance. The dialogue must continue, however, because of the issue's importance.

\section{References}

Amariglio, J., Resnick, S. and Wolff, R. D. (1993) Division and difference in the "Discipline" of economics. In E. Messer-Davidow, D. R. Shumway and D. J. Sylvan, editors, Knowledges: Historical and Critical Studies in Disciplinarity. Charlottesville: University Press of Virginia, 150-184.

Aspinall, P. (2007) Approaches to developing an improved cross-national understanding of concepts and terms relating to ethnicity and race. International Sociology, 22: 41-70.

Bastow, S., Tinkler, J. and Dunleavy, P. (2014) The Impact of the Social Sciences: How Academics and their Research Make a Difference. London: SAGE.

Batty, M. (2013) The New Science of Cities. Cambridge, MA: The MIT Press.

Baudains, P, Johnson, S. D. and Braithwaite, A. M. (2013) Geographic patterns of diffusion in the 2011 London riots. Applied Geography, 45: 211-219.

Bell, A., Johnston, R. J. and Jones, K. (2014) Stylised facts or situated messiness? The diverse effects of increasing debt on economic growth. Journal of Economic Geography

\footnotetext{
${ }^{30}$ An early example of such analyses is Johnston (1979).

${ }^{31}$ Rusu's (2012) entire argument regarding sociology has strong echoes for human geography. In UK sociology - and political science - however, the marginalisation of quantitative teaching has been more substantial than in human geography, as illustrated by the large number of advertised posts in the QStep programme, designed to promote the teaching of quantitative methods to UK social scientists, that are in sociology and politics departments in the host universities, rather than geography - see http://www.nuffieldfoundation.org/q-step (accessed 7 January 2014). Gilbert's $(2014,99)$ essay argues strongly against the 'growing lack of understanding of alternative approaches' among geographers and the ways in which some geographers contrast other ways of researching to their own.
} 
Berthoud, R. (1998) Defining ethnic groups: origin or ethnicity? Patterns of Prejudice, 32: 53-63.

Bickel, P. J., Hammel, E. A. and O'Connell, J. W. (1975) Sex bias in graduate admissions: data from Berkeley. Science, 187 (4175): 398-404.

Blastland, M. and Spiegelhalter, D. (2013) The Norm Chronicles: Stories and Numbers about Danger. London: Profile Books.

Castree, N., Kitchin, R. and Rogers, A. (2013) Oxford Dictionary of Human Geography. Oxford: Oxford University Press.

Cliff, A. D., Haggett, P. and Smallman-Raynor, M. (2000) Island Epidemics. Oxford: Oxford University Press.

Cloke, P., Cook, I., Crang, P., Goodwin, M., Painter, J. and Philo, C. (2004) Practising Human Geography. London: Sage.

Cloke, P., Crang, P. and Goodwin, M., editors (2014) Introducing Human Geographies (third edition). London: Routledge.

Conradson, D (2014) Health and well-being. In Cloke, P., Crang, P. and Goodwin, M., editors Introducing Human Geographies (third edition). London: Routledge, 599-612.

Cook, L. J., Hawkins, H., Sacks, S., Rawling, E., Griffiths, H., Swift, D., Evans, J., Rothnie, G., Wilson, J. and Williams, A. (2011) Organic public geographies: making the connection. Antipode, 43: 909-926.

Cox, K R. (2014) Making Human Geography. New York: Guilford.

Cresswell, T. (2013) Geographic Thought: a Critical Introduction. Chichester: WileyBlackwell.

Cresswell, T. (2014) Place. In Cloke, P., Crang, P. and Goodwin, M., editors, Introducing Human Geographies (third edition). London: Routledge, 249-261.

Curry, M. (2008) Digital Places: Living with Geographic Information Technologies. London: Routledge.

Davis, P. editor (2014) Data Inference in Observational Settings. London: Sage.

Denicolo, P. editor (2013) Achieving Impact in Research. London: SAGE.

Desrosières, A. (2011) Words and numbers: for a sociology of the statistical argument. In A. R. Sætnan, H. M. Lomell and S. Hammer (editors) The Mutual Construction of Statistics and Society. Basingstoke: Palgrave Macmillan, 41-63.

Dibben, C. and Popham, F. (2013) Are health inequalities evident at all ages? An ecological study of English mortality records. European Journal of Public Health, 23: 39-45. 
Dorling, D. (2010) Injustice: Why Social Inequality Persists. Bristol: The Policy Press.

Dustmann , C. and Fasani, F. (2013) The Effect of Local Area Crime on Mental Health. School of Economics and Finance, Queen Mary University of London, Working Paper 712.

Elwood, S., (2006) Critical issues in Particpatory GIS: deconstructions, reconstructions and new research directions. Transactions in GIS, 10: 693-708.

ESRC (2013) International Benchmarking Review of UK Human Geography. Swindon: ESRC.

Exeter, D. J., Rodgers, S. and Sabel, C. E. (2014) "Whose data is it anyway?" The implications of putting small-area health and social data online. Health Policy, 114: 88-96.

Flynn, J. R. (2012) Are We Getting Smarter? Rising IQ in the Twenty-First Century. Cambridge: Cambridge University Press.

Freeman, T. W. (1961) A Hundred Years of Geography. London: George Duckworth.

Gamble, A. M. (1988) The Free Economy and the Strong State. London: Macmillan.

Gangl, M. (2010) Causal inference in sociological research. Annual Review of Sociology, 36: 21-47.

Gilbert, D. (2014) Science-art. In Cloke, P., Crang, P. and Goodwin, M., editors, Introducing Human Geographies (third edition). London: Routledge, 96-116.

Goldacre, B. (2008) Bad Science. London: Fourth Estate.

Goldacre, B. (2012) Bad Pharma: How Drug Companies Mislead Doctors and Harm Patients. London: Fourth Estate.

Gould, P. R. (1979) Geography 1957-1977: the Augean period. Annals of the Association of American Geographers, 69, 139-151.

Goux, D. and Maurin, E. (2007) Close neighbours matter: neighbourhood effects on early performance at school. The Economic Journal 117: 1193-1215.

Graham, M. and Shelton, T. (2013) Geography and the future of big data, big data and the future of geography. Dialogues in Human Geography 3: 255-261.

Graham, S. and Wood, D. (2003) Digitizing surveillance: categorization, space, inequality. Critical Social Policy, 23, 227-248.

Green, M. (2013) The equalisation hypothesis and changes in geographical inequalities of age-based mortality in England, 2004-2004 to 2008-2010. Social Science and Medicine 87: 93-98. 
Gregory, S. (1963) Statistical Methods and the Geographer. London: Longman.

Haggett, P. (1972) Geography: a Modern Synthesis. New York: Harper \& Row

Haklay, M. (2014) Geographical information systems. In Cloke, P., Crang, P. and Goodwin, M., editors, Introducing Human Geographies (third edition). London: Routledge, 203-214.

Hall, P. (1980) Great Planning Disasters. London: Weidenfeld \& Nicolson

Hamnett, C. (2013) Shrinking the welfare state: the structure, geography and impact of British government benefit cuts. Transactions of the Institute of British Geographers doi 10.1111/tran.12049.

Hannah, M. (2010) Dark Territory in the Information Age: Learning from the West German Census Controversies of the 1980s. Farnham: Ashgate.

Harris, C. D. (1954) The market as a factor in the localization of industry in the United States Annals of the Association of American Geographers, 44: 315-348

Harris, R., Fitzpatrick, K., Souch, C., Brunsdon, C., Jarvis, C., Keylock, C., Orford, S., Singleton, A. and Tate, N. (2013) Quantitative Methods in Geography Making the Connections between Schools, Universities and Employer.

https://www.researchgate.net/publication/256191493_Quantitative_Methods_in_Geog raphy_Making_the_Connections_between_Schools_Universities_and_Employers (20 January 2014)

Harris, R., Sleight, P. and Webber, R. editors (2005) Geodemographics, GIS and Neighbourhood Targeting. Chirchester: John Wiley.

Johnson, O. (2013) Is concentrated advantage the cause? The relative contributions of neighborhood advantage and disadvantage to educational inequality. The Urban Review 45: 561-585.

Johnston, R. J. (1979) The spatial impact of fiscal changes in Great Britain: regional policy in reverse? Environment and Planning A, 11: 1439-1444.

Johnston, R. J. (1984) A foundling floundering in World Three. In M. Billinge, D. Gregory and R. Martin, editors, Recollections of a Revolution. London: Macmillan 39-56.

Johnston, R. J. (1985) Spatial analysis in British human geography: a twenty-year diversion? L'Espace Géographique, 14: 29-32.

Johnston, R. J. (199) On Human Geography. Oxford: Blackwell

Johnston, R. J. (1997) W(h)ither spatial science and spatial analysis. Futures, 29: 323-335.

Johnston, R. J., Harris, R., Jones, K., Manley, D., Sabel, C. E., and Wang, W. W. (2014) Mutual misunderstanding and avoidance, mis-representations, and disciplinary 
politics: spatial science and quantitative analysis in (UK) geographical curricula. Dialogues in Human Geography, 4:

Johnston, R. J., Pattie, C. J. and Rossiter, D. J. (2013) Manipulating territories: British political parties and new Parliamentary constituencies. Territory, Politics, Governance, 1: 223-245

Johnston, R. J. and Sidaway, J. D. (2004) Geography and Geographers: Anglo-American Human Geography since 1945 (sixth edition). London: Edward Arnold.

Johnston, R. J. and Sidaway, J. D. (2014) Have the geographical canons been silenced: or were they never primed? Journal of Historical Geography

Jones, K. (2010) The practice of quantitative methods. In B. Somekh and C. Lewin, editors, Theory and Methods in Social Research. London: SAGE Publications, 201-211

King, A. and Crewe, I. (2013) The Blunders of Our Governments. London: Oneworld Publications.

Kitchin, R. (2014) Explanation-understanding. In P. Cloke, P. Crang and M. Goodwin, editors, Introducing Human Geographies (third edition). London: Routledge, 117129.

Klein, J. T. (1993) Blurring, cracking, and crossing: permeation and the fracturing of discipline. In E. Messer-Davidow, D. R. Shumway and D. J. Sylvan, editors, Knowledges: Historical and Critical Studies in Disciplinarity. Charlottesville: University Press of Virginia, 185-211.

Kullenberg, C. (2011) Sociology in the making: statistics as a mediator between the social sciences, practice and the state. In A. R. Sætnan, H. M. Lomell and S. Hammer (editors) The Mutual Construction of Statistics and Society. Basingstoke: Palgrave Macmillan, 64-78.

Kwan, M.-P. (2002) Introduction: feminist geography and GIS. Gender, Place and Culture, 9: 261-262.

Lenoir, T. (1993) The discipline of nature and the nature of disciplines. In E. MesserDavidow, D. R. Shumway and D. J. Sylvan, editors, Knowledges: Historical and Critical Studies in Disciplinarity. Charlottesville: University Press of Virginia, 70102.

Levitan, K. (2011) A Cultural History of the British Census: Envisioning the Multitude in the Nineteenth Century. Basingstoke: Palgrave Macmillan.

Little, J. (2014) Society-space. In Cloke, P., Crang, P. and Goodwin, M., editors, Introducing Human Geographies (third edition). London: Routledge, 23-36.

Longley, P. A. and Clarke, G. editors (1995) GIS for Business and Service Planning. Cambridge: Geoinformation International. 
Luke, T. W. (1999) The discipline as disciplinary normalization: networks of research. New Political Science, 21: 345-363.

Murphy, S. (2010) The pull of PISA: uncertainty, influence and ignorance. InterAmerican Journal of Education for Democracy, 3: 28-44.

Norman, P. and Boyle, P. (2014) Are health inequalities between differently deprived areas evident at different ages? A longitudinal study of census records in England \& Wales, 1991-2001. Health and Place, 26: 88-93.

Oakley, A. (1990) Who's afraid of the randomised controlled trial? Some dilemmas of the scientific method and "good" research practice. In Roberts, H. (ed.) Women's Health Counts. London: Routledge

Pearson, A., Kingham, S., Mitchell, P. and Apparicio, P. (2013) Exploring hotspots of pneumoccal pneumonia and potential impacts of ejecta dust exposure following the Christchurch earthquakes. Spatial and Spatio-temporal Epidemiology, 7: 1-9.

Pickles, J. (ed.) Ground Truth: the Social Implications of Geographical Information Systems. New York: Guilford Press.

Rind, E., Jones, A. and Southall, H. (2013) How is post-industrial decline associated with the geography of physical activity? Evidence from the Health Survey for England. Social Science and Medicine, 104: 88-97

Rogers, S. (2013) Facts are Sacred. London: Faber and Faber.

Rusu, M. S. (2012) Multi-paradigmacity, scattered cumulativity, multi-localized ignorance: the tumultuous condition of sociological knowledge. Revista de Cercetare si Interventie Sociola, 39: 187-203.

Sabel, C. E., Boyle, P., Raab, G., Löytönen, M. and Maasilta, P. (2009) Modelling individual space-time exposure opportunities: a novel approach to unravelling the genetic or environment disease causation debate. Spatial and Spatio-temporal Epidemiology, 1, 85-94.

Sætnan, A. R., Lomell, H. M. and Hammer, S. editors (2011) The Mutual Construction of Statistics and Society. London: Routledge.

Sampson, R. J. (2012) Great American City: Chicago and the Enduring Neighborhood Effect. Chicago: University of Chicago Press.

Sampson, R. J. (2013) The place of context: a theory and strategy for criminology's hard problems. Criminology 51: 1-31.

Sayer, A. (1992) Method in Social Science: a Realist View (second edition). London: Routledge. 
Sharkey, P. and Faber, J. (2014) Where, when, why, and for whom do residential contexts matter? Moving away from the dichotomous understanding of neighborhood effects. Annual Review of Sociology

Silver, N. (2012) The Signal and the Noise: Why So Many Predictions Fail-but Some Don't. New York: Penguin Books

Syed, M. (2011) Bounce: the Myth of Talent and the Power of Practice. London: Fourth Estate.

Thompson, D. (2010) The politics of the census: lessons from abroad. Canadian Public Policy 36: 377-382.

Timmins, N. (1995) The Five Giants: a Biography of the Welfare State. London: HarperCollins.

Walton-Roberts, M., Beaujot, R., Hiebert, D., McDaniel, S., Rose, D. and Wright, R. (2014) Why do we still need a census? Views from the age of "truthiness" and the "death of evidence". The Canadian Geographer doi 10.1111/1541-0064.2013.12065.x

Wilkinson, R. and Pickett, K. (2009) The Spirit Level: Why More Equal Societies Almost Always Do Better. London: Allen Lane.

Wilson, A. G. (2000) Complex Spatial Systems: the Modelling Foundations of Urban and Regional Analysis. Harlow: Longman. 